\title{
METODE UNIVERSAL THRESHOLD DALAM TRANSFORMASI WAVELET DISKRET PADA KASUS SINYAL SUARA
}

\author{
Andriyani ${ }^{a}$, Moch. Hamsyi ${ }^{\mathrm{b}}$ \\ ${ }^{a}$ Program Studi Magister Pendidikan Matematika, Pascasarjana UAD \\ ${ }^{\mathrm{b}}$ Departemen Informatika, Institut Teknologi Sepuluh Nopember \\ Jl Pramuka 42 Sidikan, Umbulharjo Yogyakarta, andriyani@mpmat.uad.ac.id
}

\begin{abstract}
ABSTRAK
Masalah yang terjadi pada sinyal suara adalah terjadinya noise yang mengkontaminasi proses pengolahannya. Dalam hal ini, diperlukan suatu proses reduksi noise untuk mengurangi noise yang terdapat pada sinyal suara. Reduksi noise di sini dilakukan dengan menerapkan transformasi wavelet diskri yang terdiri dari tiga langkah utama yaitu: dekomposisi sinyal, proses thresholding dan rekonstruksi sinyal. Penelitian ini bertujuan untuk mengkaji metode universal threshold untuk mendapatkan nilai threshold dan aplikasinya pada kasus sinyal suara yang terkontaminasi Gaussian noise. Metode yang dilakukan adalah kajian literatur referensi-referensi terkait transformasi wavelet diskrit dan sinyal suara. Nilai threshold yang digunakan dalam proses thresholding ditentukan dengan metode universal threshold yang dikaji agar threshold yang diperoleh memberikan hasil optimal ketika dibandingkan dengan koefisien wavelet $d_{j k}^{u}$ hasil penerapan aturan hard atau soft thresholding. Hasil aplikasi dan simulasi reduksi noise dengan wavelet menunjukkan bahwa nilai SNR berbanding terbalik dengan nilai MSE, sedangkan nilai nilai threshold sebanding dengan nilai MSE.
\end{abstract}

Kata Kunci : transformasi wavelet diskrit, universal threshold, sinyal suara.

\begin{abstract}
Problems that occur in the speech ignal is the occurrence of noise that contaminates the processing. In this case, a noise reduction process is required to reduce noise in the audio signal. The noise reduction here is made by applying a discrete wavelet transforms consisting of three main steps: signal decomposition, thresholding process, and signal reconstruction. This study aims to examine the universal threshold method to obtain threshold value and its application in the case of Gaussian noise contaminated noise signal. The method used is the literature review of references related to discrete wavelet transforms and speech signals. The threshold value used in the thresholding process is determined by the universal threshold method examined so that the threshold obtained gives optimal results when compared with the wavelet coefficients resulting from the application of hard or soft thresholding rules. The result of the application and the simulation of noise reduction with wavelet shows that SNR value is inversely proportional to MSE value, while the threshold value is proportional to MSE value
\end{abstract}

Key words : discrete wavelet transforms, universal threshold, speech signals 


\section{Pendahuluan}

Pengolahan sinyal suara merupakan salah satu elemen penting dalam berbagai bidang yang melibatkan data berupa sinyal suara. Permasalahan yang sering dihadapi pada pengolahan sinyal adalah adanya noise pada waktu pengambilan data. Noise membuat suara menjadi kurang 'sempurna' sehingga dapat mempengaruhi proses pengolahannya. Oleh karena itu, diperlukan suatu proses reduksi noise yang bertujuan untuk mengurangi noise dalam sinyal suara. Proses reduksi noise ini dilakukan melalui pengurangan atau penghapusan data sinyal yang dianggap sebagai noise dan salah satu pendekatan yang dapat digunakan adalah dengan transformasi wavelet diskrit. Transformasi wavelet tersebut diterapkan di banyak bidang studi karena wavelet merupakan ekspansi dari Analisis Fourier (Amiri, G. A, \& Assadi, A., 2009). Beberapa penelitian menggunakan transformasi wavelet dalam analisis teknik rekayasa (Mahdafi, dkk, 2013; Rajasekaran, dkk, 2006; Fan \& Zuo, 2006; Phinyomark, dkk, 2011; Nikolaev, N., 2009). Wavelet adalah gelombang kecil energi yang terkonsentrasi dalam waktu (Daubechies, I., 1992). Transformasi wavelet adalah alat yang adaptif untuk analisis frekuensi waktu dalam teknik rekayasa dan memiliki kemampuan mendekomposisi frekuensi waktu yang baik. Algoritma dari reduksi noise dengan wavelet ini melibatkan tiga langkah pokok yaitu dekomposisi sinyal suara dengan transformasi wavelet diskrit, kemudian sinyal hasil transformasi dilewatkan pada suatu fungsi thresholding, dan yang terakhir melakukan rekonstruksi sinyal dengan invers transformasi wavelet diskrit. Selain jenis filter yang digunakan, pada reduksi noise dengan wavelet, kualitas sinyal hasil juga dipengaruhi oleh nilai threshold yang digunakan pada saat thresholding. Metode penentuan threshold ada bermacam-macam karena itu perlu diselidiki penentuan threshold yang memberi hasil paling optimal diantaranya adalah metode universal threshold. Nilai threshold $\lambda$ yang diperoleh melalui metode universal threshold memuat level $\hat{\sigma}$ sebagai nilai stardart deviasinya dan selanjutnya akan digunakan untuk menentukan koefisien wavelet yang signifikan melalui aturan hard atau soft thresholding, dimana nilai koefisien wavelet $d_{j k}^{u}$ akan dibandingkan dengan nilai threshold $\lambda$.

\section{Metode Penelitian}

Penelitian ini dilakukan dengan studi literatur referensi-referensi pendukung untuk memahami pengertian wavelet, prosedur transformasi wavelet diskret, 
maupun estimator-estimator threshold yang diperoleh melalui berbagai metode thresholding. Setelah mengkaji materimateri yang disebutkan di atas, dilakukan simulasi aplikasi metode estimasi threshold dengan menggunakan data sekunder sinyal suara berukuran $512 \mathrm{~Hz}$ dan analisis dengan menggunakan bantuan Matlab.

\section{a. Transformasi Wavelet Diskret}

Wavelet $\psi$ merupakan fungsi yang terdiri dari kelompok translasi dan dilatasi pada sebuah fungsi tunggal dan memiliki basis orthonormal seperti didefinisikan oleh Meyer (1992). Dalam pembentukan basis wavelet tersebut diperlukan analisis multiresolusi yang merupakan basis orthonormal untuk $L^{2}(\Re)$ (Mallat, 1999).

Suatu sampel fungsi kontinyu akan diamati dalam jumlah berhingga pada titik waktu diskret, sehingga memiliki sifat yang hampir sama dengan fungsi diskret. Karena itu, dalam analisis multiresolusi diperlukan transformasi wavelet diskret (Discrete Wavelet Transforms atau DWT) terhadap sebuah vektor fungsi u yang berada pada ruang yang sama dengan transformasi tersebut untuk menganalisis frekuensi dan waktu dari sinyal kontinyu transien (Antoniadis, dkk, 1996; Rioul, O, 1993).

Jika level resolusi terluar $j_{0}$ dan $n=2^{J}$ pengamatan untuk suatu bilangan positif $J$, maka sebuah matrik $W$ dapat digunakan untuk menghasilkan sebuah vektor koefisien wavelet dengan transformasi diskrit wavelet yang dinyatakan oleh $\mathbf{d}=$ Wu dimana d adalah vektor $n x l$ yang memuat koefisien skala diskrit, $c_{j_{0} k}, k=0, \ldots, 2^{j_{0}}-1$, dan koefisien wavelet diskrit, $\quad d_{j k}, j=j_{0}, . . J-1, k=0, . .2^{j}-1$ sedangkan $W$ adalah matrik orthogonal berukuran $n x n$ yang berkaitan dengan pemilihan basis wavelet yang orthonormal. Karena orthogonalitas dari matrik $W$, maka invers transformasi diskrit wavelet (Inverse Discrete Wavelet Transforms atau IDWT) diberikan oleh $\mathbf{g}=W^{-1} \mathbf{d}$, dengan $\mathbf{g}=\hat{\mathbf{u}}$ (Delyon\&Juditsky, 1995).

\section{b. Estimasi Threshold}

Gagasan utama dalam kasus sinyal suara adalah mendapatkan komponenkomponen sinyal yang ideal dari sinyal yang terkontaminasi noise (gangguan) dan mengestimasi level noise. Terdapat beberapa penelitian terkait pendekatan ataupun metode yang dapat digunakan untuk mengestimasi level noise seperti yang dilakukan oleh Greiff, dkk (2002); Ergen (2013) dan Effern, dkk (2000). Dalam hasil penelitiannya, ada empat threshold berbeda yang dapat digunakan untuk melihat keefektifan mendapatkan sinyal ideal. Salah satu metodenya adalah Sqtwolog yang didefinisikan sebagai universal threshold dengan nilai threshold $\lambda^{\text {Univ }}=\hat{\sigma} \sqrt{2 \ln n}$. 
c. Simulasi aplikasi metode universal threshold pada kasus sinyal suara

Suatu suara $g\left(t_{i}\right)$ merupakan fungsi kontinyu yang menunjukkan frekuensi suara pada ruang satu dimensi, dimana $g\left(t_{i}\right)$ memetakan titik-titik sampel pada interval waktu tertentu. Untuk suatu titik sampel $t_{i}$, frekuensi suara yang dimiliki setiap titiknya dinyatakan dengan $g\left(t_{i}\right)$ pada $[0,1]$ sedemikian hingga $t_{i}=\frac{i}{n}$. Setiap sampel memberi informasi untuk memancarkan kembali gelombang suara seakurat mungkin dengan range gerak dan frekuensi yang berbeda. Karena sifat kontinyu data sinyal suara, maka frekuensi $g\left(t_{i}\right)$ yang berhingga pada nilai tertentu dapat dinyatakan dengan $L_{\min } \leq g(t) \leq L_{\max } \quad ; \quad L_{\min }=-L_{\max }$ menyatakan nilai minimum dan maksimum dari frekuensi suara.

Simulasi aplikasi metode universal threshold dilakukan pada sampel data sekunder sinyal suara dengan ukuran $512 \mathrm{~Hz}$ yang terkontaminasi pada tingkat SNR berbeda oleh noise Gaussian putih. SNR yang berGaussian Noise berukuran $10 \mathrm{~dB}, 50 \mathrm{~dB}$ dan 100 dB. Karena sinyal terkontaminasi noise, maka variabel fungsi dari $\mathbf{g}$ menjadi u .

\section{Hasil dan Pembahasan}

Estimasi fungsi $g\left(t_{i}\right)$ pada model regresi nonparametrik $u_{i}=g\left(t_{i}\right)+\varepsilon$ dengan Gaussian noise berukuran $n=2^{J}$, dapat diperoleh melalui beberapa pendekatan yang didasarkan atas deret orthogonal atau kombinasi linier sejumlah fungsi basis seperti wavelet. Fungsi respon $u_{i}$ kontinyu pada domain waktu dengan titik data yang saling berkorelasi. Untuk menghilangkan sifat korelasi tersebut diperlukan suatu transformasi wavelet diskret dalam bentuk translasi dan dilatasi d $=$ Wu. sehingga $u_{i}$ yang berada dalam domain waktu dan frekuensi tidak mengandung korelasi antara sinyal dan noisenya.

Dari transformasi wavelet $\mathbf{d}$, diperoleh koefisien skala $c_{j_{0} k}^{u}$ dan koefisien wavelet $d_{j k}^{u} \quad$ yang memiliki sifat kejarangan (sparsity). Jika koefisien wavelet $d_{j k}^{u}$ bernilai besar (frekuensi tinggi), maka koefisien tersebut membawa banyak informasi tentang sinyal. Sebaliknya, jika koefisien wavelet $d_{j k}^{u}$ bernilai kecil (frekuensi rendah) maka koefisien membawa banyak informasi tentang noise. Estimator koefisien wavelet $\hat{d}_{j k}$ diperoleh melalui pendekatan thresholding dengan langkah awal menentukan level noise $\hat{\sigma}$. Salah satu metode estimasi yang dapat 
digunakan untuk mengestimasi $\hat{\sigma}$ pada level terbaik $J$ adalah Median Absolute Deviation Normal (MADN).

Misalkan $\mathrm{p}$ adalah sembarang koefisien wavelet sedemikian hingga jumlah data koefisien pada setiap sisinya sama, maka median dari himpunan koefisien dinotasikan dengan:

$\mathrm{p}=\operatorname{median}\left(d_{j k}^{u}\right)$

untuk \#\{ $\left.d_{j k}^{u}>\mathrm{p}\right\}=\#\left\{d_{j k}^{u}<\mathrm{p}\right\}$, dengan $\#\left\{d_{j k}^{u}\right\}$ menyatakan jumlah elemen dari himpunan koefisien wavelet. Karena $j=j_{0}, \ldots, J, k=0, \ldots, 2^{J}-1 \quad$ dan batas terbesar level resolusi ke- $j$ koefisien wavelet adalah $J-1$, median koefisien wavelet yang berhenti pada level resolusi terbaik $J$ adalah $\quad \mathrm{p}=$ median $\left(d_{J-1, k}^{u}\right.$ ). Misalkan koefisien wavelet diurutkan secara statistik $d_{j_{0} k}^{u} \leq . . \leq d_{j k}^{u}$, untuk $J-1=2 r-1, r \in \mathrm{Z}$ bernilai ganjil, maka $\operatorname{Med}\left(d_{J-1, k}^{u}\right)=d_{r, k}^{u}$. Untuk suatu level $J-$ 1 yang bernilai genap, maka Med $\left(d_{J-1, k}^{u}\right)$ $=\frac{d_{r, k}^{u}+d_{r+1, k}^{u}}{2}$

Kebaikan estimasi untuk simpangan baku $(\sigma)$ diperoleh melalui median absolute deviation (MAD) yang didefinisikan oleh: $\operatorname{MAD}\left(d_{J-1, k}^{u}\right)=\operatorname{Median}\left\{\left|d_{J-1, k}^{u}-\operatorname{Median}\left(d_{J-1, k}^{u}\right)\right|\right\}$ Median absolute deviation normal
(MADN) dinyatakan oleh $\hat{\sigma}=\operatorname{MADN}\left(d_{J-1, k}^{u}\right)=\frac{\operatorname{MAD}\left(d_{J-1, k}^{u}\right)}{0,6745}$, dengan 0,6745 adalah MAD dari variabel berdistribusi normal baku. Estimasi MADN $\left(d_{J-1, k}^{u}\right)$ di atas mengacu pada optimalisasi estimasi klasik dengan asumsi model berdistribusi normal dan minimum gangguannya (outlier). Oleh karena itu, MADN $\left(d_{J-1, k}^{u}\right)$ dianggap sebagai estimasi robust yang menunjukkan estimasi level noise pada level resolusi terbaik $J$.

Dengan asumsi bahwa penghilangan koefisien wavelet yang bernilai kecil tidak akan merubah sifat data asli, maka digunakan aturan soft atau hard thresholding untuk menghilangkan noise dengan cara menjadikan koefisien bernilai nol atau mengurangi nilainya dengan batas ambang $\lambda$ tertentu. Nilai threshold $\lambda$ pada kedua aturan thresholding dapat diperoleh melalui metode universal threshold yang memuat level $\hat{\sigma}$ sebagai nilai stardart deviasinya.

\section{a. Universal Threshold}

Sifat orthogonal dan linier pada transformasi wavelet mengakibatkan model domain wavelet sama dengan domain pada persamaan $u_{i}=g\left(t_{i}\right)+$ $\varepsilon_{i}, i=1,2, \ldots, n \quad$ sehingga diperoleh: $\mathbf{w}=\mathbf{v}+\boldsymbol{\omega}$ 
Misalkan:

$I_{0}=\left\{i=1, \ldots, n \mid v_{i}=0\right\}, I_{1}=\left\{i=1, \ldots, n \mid v_{i} \neq 0\right\}$,

$M_{0}=\# I_{0}, M_{1}=\# I_{1}$.

dengan \# adalah jumlah elemen. Karena $M_{0}$ dan $M_{1}$ tergantung pada $n$, dan pada setiap level hanya terdapat sebuah koefisien $v_{i} \neq 0$, maka jumlah total dari koefisien $v_{i} \neq 0$ adalah proporsi dari jumlah level-levelnya, sedemikain hingga berlaku: $M_{1} \approx \log n$ dan $\frac{M_{1}}{n} \rightarrow 0$. Pada $\mathrm{E}(\mathrm{R}(\lambda))=\frac{1}{\mathrm{n}}\left\|\mathrm{E} \mathbf{w}_{\lambda}-\mathbf{v}\right\|^{2}$ dan $\|$.$\| adalah$ norm dari fungsi bias, ditunjukkan bahwa fungsi resiko sama dengan nilai bias ditambahkan dengan varians yang nilainya mendekati nol akibat penggantian koefisien terkecil dengan nilai nol. Karena itu, fungsi resiko pada koefisien wavelet dapat dinyatakan dengan

$\mathrm{E} R^{\prime}(\lambda)=\frac{\partial\left(\sum_{i=1}^{n} r\left(v_{i}, \lambda\right)\right)}{\partial \lambda}$ sama dengan nilai biasnya. Melalui $r\left(v_{i}, \lambda\right)=\mathrm{E}\left(w_{i}-v_{i}\right)^{2} \quad$ diperoleh konstribusi setiap elemen vektor koefisien w terhadap fungsi resiko dan total konstribusi terhadap fungsi resikonya yang dapat dinyatakan dengan: $\sum_{i=1}^{n} r\left(v_{i}, \lambda\right)=\mathrm{E} R(\lambda)$ sehingga diperoleh

$$
\begin{aligned}
E R^{\prime}(\lambda) & =\frac{\partial\left(\sum_{i=1}^{n} r\left(v_{i}, \lambda\right)\right)}{\partial \lambda} \\
& =M_{0} \frac{\partial r}{\partial \lambda}(0, \lambda)+\sum_{i=I_{1}} \frac{\partial r}{\partial \lambda} r\left(v_{i}, \lambda\right)
\end{aligned}
$$

Untuk memperoleh nilai threshold, $\lambda$, yang optimal maka persamaan (1) harus memenuhi

$\mathrm{E}\left(R^{\prime}(\lambda)\right)=0$

Misalkan $I_{1}^{\prime} \subset I_{1}$ merupakan koefisien tidak nol yang bernilai negatif, sedangkan $I_{1}^{\prime \prime}$ adalah koefisien yang tidak nol bernilai positif, sedemikianhingga $M_{1}^{\prime}=\# I_{1}^{\prime}, M_{1}^{\prime \prime}=\# I_{1}^{\prime \prime}$ maka persamaan (2) dapat dinyatakan oleh $0=M_{0} \frac{\partial r}{\partial \lambda}(0, \lambda)+\sum_{i \in I_{1}} \frac{\partial r}{\partial \lambda}\left(v_{i}, \lambda\right)+\sum_{i \in I_{1}^{\prime}} \frac{\partial r}{\partial \lambda}\left(v_{i}, \lambda\right)$

dan

$-M_{0} \frac{\partial r}{\partial \lambda}(0, \lambda)-\sum_{i \in I_{1}^{\prime}} \frac{\partial r}{\partial \lambda}\left(v_{i}, \lambda\right)=\sum_{i \in I_{1}^{I}} \frac{\partial r}{\partial \lambda}\left(v_{i}, \lambda\right)$

Tanda negatif pada ruas kiri $M_{0} \frac{\partial r}{\partial \lambda}(0, \lambda)$ memenuhi kondisi derivatif konstribusi dengan resiko terkecil untuk $\lambda \rightarrow \infty$ yang menunjukkan bahwa $\frac{\partial r}{\partial \lambda}(0, \lambda)<0$ dan nilai $\sum_{i \in I_{1}^{\prime}} \frac{\partial r}{\partial \lambda}\left(v_{i}, \lambda\right)<0$, sedemikian hingga kedua ruas dapat dikelompokkan menjadi fungsi yang berlawanan nilai. /.

Untuk $M_{1}^{\prime} \leq M_{1} \approx \log n$ dan $M_{0} \approx n$, proporsi jumlah koefisien fungsi pada ruas kiri dapat dinyatakan dengan 


$$
\begin{aligned}
\frac{M_{1}^{\prime}}{M_{0}} \approx \frac{\log n}{n} & =\lim _{n \rightarrow \infty} \frac{\log n}{n} \\
& =\lim _{n \rightarrow \infty} \frac{1 / n \log e}{1} \\
& =\lim _{n \rightarrow \infty} \frac{1}{n} \log e \\
& =\frac{1}{\infty} \log e=0
\end{aligned}
$$

Dengan demikian, pengaruh jumlah $\sum_{i \in I_{1}^{\prime}} \frac{\partial r}{\partial \lambda}\left(v_{i}, \lambda\right)$ pada (3) tidak signifikan dan

(3) dapat ditulis kembali dengan

$$
-M_{0} \frac{\partial r}{\partial \lambda}(0, \lambda)=\sum_{i \in I_{1}^{\prime \prime}} \frac{\partial r}{\partial \lambda}\left(v_{i}, \lambda\right)
$$

Jika $v_{i} \rightarrow \infty$ pada $\sum_{i \in I_{1}^{\prime \prime}} \frac{\partial r}{\partial \lambda}\left(v_{i}, \lambda\right)$ maka dengan menggunakan derivatif konstribusi yang memuat resiko seminimum mungkin diperoleh:

$$
\begin{aligned}
\frac{\partial r}{\partial \lambda}(\infty, \lambda) & =2 \lambda[1+\Phi(\infty)-\Phi(\infty)]-2 \sigma^{2}[\rho(\infty)+\rho(\infty)] \\
& =2 \lambda[1+0]-2 \sigma^{2}[0+0] \\
& =2 \lambda
\end{aligned}
$$

Akibatnya persamaan (4) menjadi :

$$
\begin{aligned}
-M_{0} \frac{\partial r}{\partial \lambda}(0, \lambda) & =M_{1}^{\prime \prime} 2 \lambda[, \\
\frac{M_{0}}{M_{1}^{\prime \prime}} & =\frac{2 \lambda}{-\frac{\partial r}{\partial \lambda}(0, \lambda)}
\end{aligned}
$$

Dengan menyubstitusikan nilai derivatif konstribusi dengan resiko terkecil untuk $\lambda \rightarrow \infty, \frac{\partial r}{\partial \lambda}(0, \lambda)$, pada (5) diperoleh:

$$
\begin{aligned}
\frac{M_{0}}{M_{1}^{\prime \prime}} & =\frac{2 \lambda}{-\left(-4 \sigma^{4} \frac{\rho(\lambda)}{\lambda^{2}}\right)} \\
& =\frac{2 \lambda \lambda^{2}}{4 \sigma^{4} \rho(\lambda)} \\
& =\frac{\lambda^{3}}{2 \sigma^{4}\left(\frac{1}{\sqrt{2 \pi}} e^{-\lambda^{2} / 2 \sigma^{2}}\right)} \\
& =\frac{\lambda^{3} \sqrt{2 \pi}}{2 \sigma^{3} e^{-\lambda^{2} / 2 \sigma^{2}}}
\end{aligned}
$$

(6)

Jika (6) dinyatakan dalam logaritma natural $(\ln )$ maka diperoleh

$$
\frac{\sigma^{3} M_{0}}{M_{1}^{\prime \prime}}=\sqrt{\frac{\pi}{2}} e^{\lambda^{2} / 2 \sigma^{2}} \lambda^{3}
$$

$3 \ln \sigma+\ln M_{0}-\ln M_{1}^{\prime \prime}=\frac{\lambda^{2}}{2 \sigma^{2}} \ln e+3 \ln \lambda+\frac{1}{2} \ln (\pi / 2)$

Kedua ruas dikelompokkan menjadi fungsi yang hanya bergantung pada nilai $n$ dan fungsi yang tergantung pada nilai $\lambda$. Dengan menyubstitusikan level noise $\hat{\sigma}$ hasil estimasi robust $\sigma$ koefisien wavelet $d_{j k}^{u}$ yang berada pada level resolusi terbaik sebagai standart deviasi $\sigma$ pada persamaan logaritma natural dengan koefisien bernilai $(-1,1)$ dan $\lambda=1,7815 \hat{\sigma}$ sebagai nilai $\lambda$ minimum, maka untuk $3 \ln \hat{\sigma} \approx 0 \quad, \quad 3 \ln \lambda \approx 0 \quad$ dan untuk $M_{1}^{\prime \prime} \leq M_{1} \approx \log n \quad$ serta $\quad M_{0} \approx n$, persamaan tersebut menjadi 


$$
\begin{aligned}
& 0+\ln n-\ln (\log n)=\frac{\lambda^{2}}{2 \hat{\sigma}^{2}} \ln e+0+\frac{1}{2} \ln (\pi / 2) \\
& \ln \left(\frac{n}{\log n}\right)-\frac{1}{2} \ln (\pi / 2)=\frac{\lambda^{2}}{2 \hat{\sigma}^{2}} \\
& \ln \left(\frac{n}{(\log n)(\pi / 2)^{1 / 2}}\right)=\frac{\lambda^{2}}{2 \hat{\sigma}^{2}}
\end{aligned}
$$

Karena untuk $n \rightarrow \infty$,

$$
\begin{aligned}
\lim _{n \rightarrow \infty} \frac{n}{(\log n)(\pi / 2)^{1 / 2}} & =\lim _{n \rightarrow \infty} \frac{1}{(1 / n \log e)(\pi / 2)^{1 / 2}} \\
& =(\pi / 2)^{-1 / 2} \lim _{n \rightarrow \infty} \frac{n}{(\log e)} \\
& =(\pi / 2)^{-1 / 2}(\log e)^{-1} \lim _{n \rightarrow \infty} n \\
& =(\pi / 2)^{-1 / 2}(\log e)^{-1} \infty \\
& =\lim _{n \rightarrow \infty} n
\end{aligned}
$$$$
\operatorname{maka}\left(\frac{n}{(\log n)(\pi / 2)^{1 / 2}}\right) \approx n \text {, sehingga }
$$$$
\ln n=\frac{\lambda^{2}}{2 \hat{\sigma}^{2}}
$$$$
\lambda^{2}=2 \hat{\sigma}^{2} \ln n
$$$$
\lambda= \pm \hat{\sigma} \sqrt{2 \ln n}
$$

Nilai $\lambda$ yang diperoleh tersebut hanya diambil yang bernilai positif dan dilambangkan dengan $\lambda^{\text {Univ }}=\hat{\sigma} \sqrt{2 \ln n}$. Nilai threshold $\lambda$ digunakan untuk menentukan koefisien wavelet yang signifikan melalui aturan hard atau soft thresholding, dimana nilai koefisien wavelet $d_{j k}^{u}$ akan dibandingkan dengan nilai threshold $\lambda$ sebagai berikut:

$$
\begin{aligned}
& \delta_{\lambda}^{H}\left(d_{j k}^{u}\right)=\left\{\begin{array}{cc}
0, & \text { jika }\left|d_{j k}^{u}\right| \leq \lambda \quad(\text { kill }) \\
d_{j k}^{u}, & \text { jika }\left|d_{j k}^{u}\right|>\lambda \quad \text { (keep) }
\end{array}\right.
\end{aligned}
$$

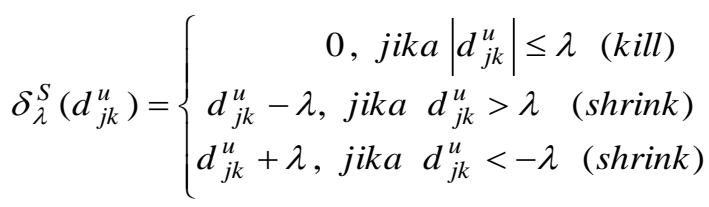

Hasil $\delta_{\lambda}\left(d_{j k}^{u}\right)=\hat{d}_{j k}$ dari penerapan aturan thresholding dan $c_{j_{0} k}^{u}=\hat{c}_{j_{0} k}$, digunakan untuk merekonstruksi fungsi $g\left(t_{i}\right)$ melalui Invers Discrete Wavelet Transforms (IDWT) berikut $\hat{\mathbf{g}}_{\lambda}=W^{-1} \mathbf{d}$, dimana $W^{-1}$ adalah invers dari matrik orthogonal wavelet. Sehingga estimasi dari fungsi $g\left(t_{i}\right)$ dapat ditulis dengan

$$
\hat{g}\left(t_{i}\right)=\sum_{k=0}^{2^{j_{0}}-1} \hat{c}_{j_{0} k} \phi_{j_{0} k}(t)+\sum_{j=j_{0}}^{J-1} \sum_{k=0}^{2^{j}-1} \hat{d}_{j k} \psi_{j k}(t)
$$

Fungsi $g\left(t_{i}\right)$ merupakan kombinasi linier suatu nilai pendekatan fungsi sebarang skala berindeks $j$ ditambah beberapa fungsi detil dengan skala dari $j_{0}$ mengecil sampai $\quad 2^{j_{0}}-1 \quad$ sesuai proses multiresolusinya.

Secara sederhana, estimasi fungsi $g\left(t_{i}\right)$ dari data kontinyu yang didiskretkan melalui pendekatan wavelet thresholding dapat dinyatakan dalam diagram berikut ini:

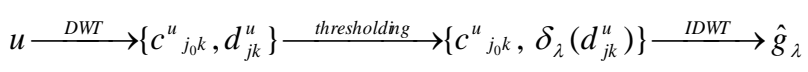

\section{b. Aplikasi metode universal threshold pada kasus sinyal suara (Speech).}


Dalam teknik komunikasi, persoalan yang sering dihadapi adalah mengusahakan agar informasi yang ditransmisikan dapat diterima dengan jelas tanpa kehilangan detailnya sedikitpun, sehingga kualitas suara yang diperoleh cukup baik, sedangkan sistem serta sarana transmisinya banyak mengandung muatan noise. Oleh karena itu, untuk memperoleh informasi sinyal yang dikehendaki pada saat terkontaminasi noise, digunakan pendekatan thresholding untuk mencari estimator wavelet pada kasus sinyal suara (speech) terkontaminasi Gaussian noise.

Suatu sampel data sekunder sinyal suara yang dinyatakan sebagai variabel $S p c$ dengan ukuran $512 \mathrm{~Hz}$, diinputkan dalam fungsi g yang merupakan sinyal asli. Dengan menggunakan fungsi Matlab awgn (add white Gaussian noise), dilakukan penambahan Gaussian noise bernilai SNR $10 \mathrm{~dB}, 50 \mathrm{~dB}$ dan $100 \mathrm{~dB}$, sehingga sinyal terkontaminasi noise dan menjadi variabel fungsi $\mathbf{u}$. Untuk mengetahui pola $\mathbf{g}$ maupun u sebagai langkah awal diperiksa visual grafik pada setiap ukuran datanya.
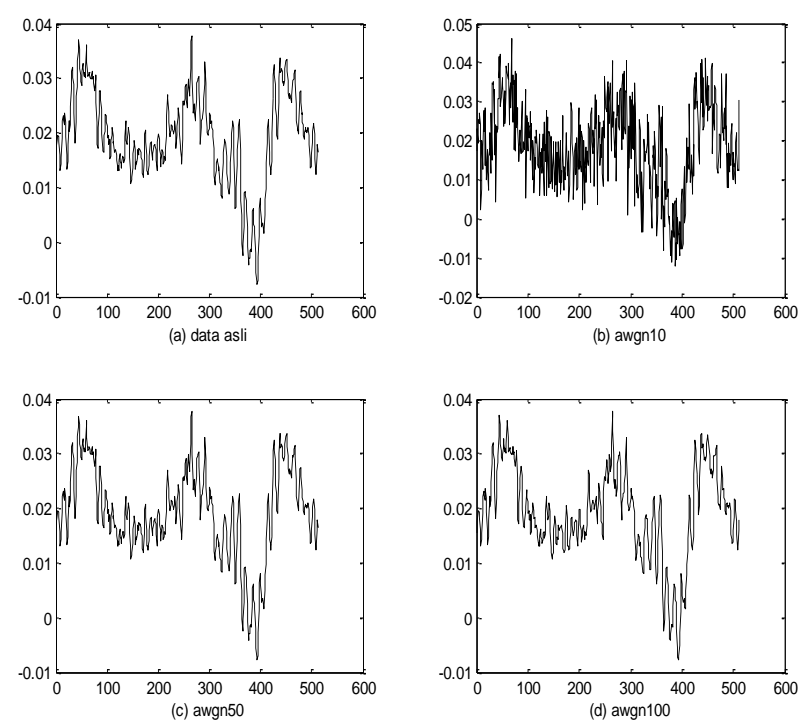

Gambar 1. Kurva Data Spc. (a) data asli $S p c$, (b) data $S p c$ yang terkontaminasi Gaussian noise dengan SNR = $10 \mathrm{~dB}$, (c) data $S p c$ yang terkontaminasi Gaussian noise dengan $\mathrm{SNR}=50 \mathrm{~dB}$, (c) data $S p c$ yang terkontaminasi Gaussian noise dengan $\mathrm{SNR}=100 \mathrm{~dB}$

Gambar 1 menggambarkan bahwa kurva variabel $\mathbf{g}$ dan $\mathbf{u}$ berukuran 512 memiliki pola yang tidak teratur (bukan liner, kuadratik ataupun pola orde yang lebih tinggi) sehingga cukup beralasan untuk memodelkannya dalam sebuah model regresi nonparametrik. Karena pada variabel $\mathbf{u}$ terdapat korelasi antara sinyal asli dan sinyal noise dalam suatu domain waktu, maka perlu dilakukan transformasi yang dapat menguraikan sinyal (domain waktu) menjadi komponen-komponen sinyal tertentu (domain frekuensi), yaitu transformasi wavelet diskret yang dapat menguraikan sinyal terkontaminasi 
Gaussian noise menjadi koefisienkoefisien skala $c_{j_{0} k}^{u}$ dan koefisienkoefisien wavelet $\quad d_{j k}^{u} \quad$.Untuk mempermudah (efisiensi) perolehan estimator wavelet melalui pendekatan thresholding, maka secara komputasi dapat digunakan bantuan software MatLab 6.5, WavLab dan unit fungsi make_Thresh sesuai dengan algoritma.

Sebelumnya, ditentukan level resolusi terluar $j_{0}=3$ dan level resolusi terbaik $J=$ 8, 9 dan 10 secara komputasi. Dengan menggunakan basis wavelet Haar dan $\alpha=0.5$, penghitungan Discrete Wavelet Transforms (DWT) dilakukan dengan fungsi MatLab FWT_PO (Forward Wavelet Transform PeriodizedOrthogonal). Berikutnya, estimasi level noise $\hat{\sigma}$ dilakukan dengan fungsi NormNoise, yang berfungsi untuk memperoleh nilai dari MADN (Median Absolute Deviation Normal) pada WavLab. Nilai $\hat{\sigma}$ tersebut akan digunakan untuk menentukan nilai threshold $\lambda$ yang diperoleh melalui metode universal threshold dan minimum MSE threshold.

Dengan membuat unit fungsi universal_threshold, yang berfungsi untuk memperoleh nilai threshold $\lambda$ dari metode universal threshold diperoleh nilai-nilai threshold $\lambda$ yang akan diinputkan kembali dalam unit SoftThresh, yang berfungsi sebagai prosedur penerapan aturan soft thresholding dan HardThresh, yang berfungsi sebagai prosedur penerapan aturan hard thresholding untuk memperoleh koefisien $\delta\left(d_{j k}^{u}\right)=\hat{d}_{j k} \quad$. Selanjutnya, estimator koefisien hasil penerapan kedua aturan thresholding tersebut akan ditransformasi lagi dengan menggunakan fungsi MatLab IWT_PO (Inverse Wavelet Transform Periodized-Orthogonal) yang merupakan fungsi invers dari transformasi wavelet diskret, sehingga diperoleh estimator $\hat{g}\left(t_{i}\right)$ dalam bentuk deret wavelet.

Dari aplikasi pendekatan thresholding, baik secara perhitungan matematis maupun menggunakan bantuan software MatLab diperoleh output komputasi estimator wavelet yang diidentifikasi berdasarka nilai MSE sebagai berikut.

Tabel. 1 Analisa Estimator Wavelet pada Data Sinyal Suara $(S p c) n=512$

\begin{tabular}{|c|c|c|c|c|c|}
\hline \multirow[t]{2}{*}{ j0 } & \multirow[t]{2}{*}{$\mathbf{J}$} & \multirow[t]{2}{*}{$\begin{array}{l}\text { SNR } \\
\text { (dB) }\end{array}$} & $\begin{array}{c}\text { Nilai } \\
\text { Threshold }\end{array}$ & Tipe & MSE \\
\hline & & & Universal & Thresholding & Universal \\
\hline \multirow[t]{6}{*}{3} & 9 & \multirow[t]{2}{*}{10} & 2.03E-02 & Hard & $1.80 \mathrm{E}-05$ \\
\hline & & & & Soft & $2.65 \mathrm{E}-05$ \\
\hline & & \multirow[t]{2}{*}{50} & $4.83 \mathrm{E}-03$ & Hard & $3.71 \mathrm{E}-06$ \\
\hline & & & & Soft & $7.00 \mathrm{E}-06$ \\
\hline & & \multirow[t]{2}{*}{100} & $4.86 \mathrm{E}-03$ & Hard & $3.03 \mathrm{E}-06$ \\
\hline & & & & Soft & 7.04E-06 \\
\hline
\end{tabular}

Tabel. 1 memperlihatkan bahwa nilai MSE variabel Spc pada SNR 100 dB memiliki nilai lebih kecil daripada SNR 
$10 \mathrm{~dB}$ dan $50 \mathrm{~dB}$, sehingga nilai SNR berbanding terbalik dengan nilai MSE. Selain itu juga ditunjukkan bahwa semakin kecil nilai threshold, maka nilai MSE juga semakin kecil. Jika dilihat dari penerapan aturan thresholdingnya, nilai MSE pada aturan hard lebih kecil daripada aturan soft. Misalnya, pada $S p c$ dengan SNR $10 \mathrm{~dB}$, MSE pada universal threshold dengan aturan hard thresholding adalah 1,8000E-05 lebih kecil daripada MSE menggunakan aturan soft thresholding yang bernilai $2,6520 \mathrm{E}-$ 05.

\section{Kesimpulan}

Dalam transformasi wavelet diskrit, nilai threshold yang akan digunakan dalam aturan thresholding diperoleh melalui metode universal threshold. Metode ini menggunakan sifat orthogonal dan linier pada transformasi wavelet yang mengakibatkan model domain wavelet sama dengan domain pada persamaan regresi nonparametrik serta kontribusi pada fungsi resikonya. Sedangkan penerapan threshold hasil dari metode universal threshold tersebut terhadap kasus data sinyal suara menunjukkan bahwa nilai threshold sebanding dengan nilai MSE, namun nilai SNR berbanding terbalik dengan nilai MSEnya.

\section{Ucapan Terimakasih}

Penulis mengucapkan terima kasih kepada Prodi Magister Pendidikan Matematika, Universitas Ahmad Dahlan terkait fasilitas diskusi dan pengolahan data yang diberikan selama penelitian sampai penulisan publikasi ini.

\section{Pustaka}

Amiri, G. G, and Asadi, A. 2000, Comparison of Different Methods of Wavelet and Wavelet Packet Transform, International Journal of Civil Engineering. 7(4): 248-257.

Antoniadis, A., Bigot, J. and Sapatinas, T., 2001, Wavelet Estimators in Nonparametric Regresión: A Comparative Simulation Study, Journal of Statistical Software, 6(6):1-83.

Daubechies I., 1992, Ten lectures on wavelets. Vermont: CBMS NSF Conference Series in Applied Mathematics, Montpelier.

Delyon, B. and Juditsky, A., 1995. Estimating Wavelet Coefficients in Wavelets and Statistics. Antoniadis, A. dan Oppenheim, G. (Eds), Lect. Notes Statist., 103, pp. 15-168.

Effern, A., Lehnertz, k., Schreiber, T., Grundwald, T., David, P. and 
Elger, C. E. 2000, Nonlinear Denoising of Transient Signals with Application to Event-related Potentials, Physica, 140: 257266.

Ergen, B. 2013, “Comparison of Wavelet Types and Thresholding Methods on Wavelet Based Denoising of Heart Sounds" in Journal of Signal and Information Processing, pp. 164167

Fan X, and Zuo MZ. 2006, Gearbox fault detection using Hilbert and wavelet packet transform, Mechanical Systems and Signal Processing, 20: 966 -982.

Greiff, H. F.C, Garcia, R.R and L-Ginori, J. V. 2002, Signal De-noising in Magnetic Resonance Spectroscopy Using Wavelet Transforms, 14(6): 388-401.

Mahdavi, F. A., Ahmad, S. A., Marhaban, M. H. and Akbarzadeh-T,M-R. 2013, The Utility of Wavelet Transform in Surface Electromyography Feature Extraction - A Comparative Study of Different Mother Wavelets. International Journal of Biomedical and Biological Engineering, 7(2): 107-112.
Mallat, S. G., 1999, A Wavelet Tour of Signal Processing, London : Second edition Academic press.

Meyer, Y., 1992, Wavelets and Operator, Cambridge:

Cambridge University Press.

Nikolaev N, Nikolov Z, Gotchev A, Egiazarian K. 2000, "Wavelet domain Wiener filtering for ECG denoising using improved signal estimate" in IEEE International Conference on Acoustics, Speech, and Signal Processing, pp 3578-3581.

Phinyomark, A., Limsakul, C. and Phukpattaranont, P. 2011, Application of wavelet analysis in EMG feature extraction for pattern classification. Measurement Science Review, 11(2): 45-52.

Rajasekaran, S., Latha, V. and Lee, S.C. 2006, Generation of artificial earthquake motion records using wavelets and principal component analysis, Journal of Earthquake Engineering, 10(5): 665-691.

Rioul, O., 1993, "Discrete-Time Multiresolution Theory," in IEEE Trans. on Signal Processing: pp. 2591-2605. 